\title{
TAXING THE INCOME OF THE CLOSE CORPORATION
}

\author{
Charles L. B. Lowndes*
}

Although there is no substantial agreement about how the income from close corporations should be taxed, there appears to be virtual unanimity with respect to the defects of the present system.

The basic weakness of the method adopted by the federal income tax for taxing corporate income is that it is predicated upon a legal fiction which ignores economic realities. In the case of a partnership, the partnership is disregarded and the partners are taxed directly upon their distributive shares of the partnership income. ${ }^{1}$ In the case of a corporation, however, the law gives full credence to the corporate fiction. Although in substance a close corporation represents an incorporated partnership, or perhaps an incorporated sole proprietorship, the corporate entity is treated as an independent taxable entity, and the income of the undertaking is taxed to the legal convention, rather than to the real owners of the enterprise.

The recognition of the corporation as a distinct taxable entity has several unhappy corollaries. Even in the case of the publicly owned corporation, it results in a complete disregard of the ability to pay principle, which is supposed to be one of the cardinal desiderata of an income tax. Although there is considerable speculation about the actual incidence of the corporate income tax, ${ }^{2}$ and whether the burden of the tax is shifted to the consumer in the form of higher prices, or to the corporate employees in the form of lower wages, or to the stockholders in the form of diminished dividends, it is clear that the actual burden of the tax is not imposed upon the corporation, which is a legal fiction. The corporate tax, which in recent years has been graduated according to the size of the corporate income, obviously bears no relation to the wealth or the ability to pay of the person who actually pays the tax, whoever he may be.

In the case of close corporations there are more fundamental objections to the current system of taxing corporate income. Some taxes are unjust because they bear

* A.B. 1923, Georgetown University; LL.B. 1926, S.J.D. I931, Harvard University. Professor of Law, Duke University.

1 The first federal income taxes, passed during the Civil War, taxed the income of corporations in the same way, that is, they ignored the corporate entity and taxed the shareholders directly upon their distributive shares of the corporate income. This system was sustained in Collector v. Hubbard, 12 Wall. I (U. S. 1870), although the Supreme Court later repudiated the Hubbard case in Eisner v. Macomber, 252 U. S. 189, at 217-219 (1920), declaring that "the stockholder's share in the accumulated profits of the company is capital, not income" (p. 2r9), and that he realizes no income upon which he may be taxed under the Sixteenth Amendment until the corporate profits are distributed to him in the form of dividends.

${ }^{2}$ Slitor, Economic Aspects of the Tax on Corporate Income, Lectures on Taxation of Bustness ENTERPRISE 28, 32-38 (I95I). 
too heavily upon a particular class of taxpayers. Others lack equity because they are susceptible to manipulation which makes it possible for the sophisticated taxpayer to shift his legitimate share of the tax burden to some more ingenuous citizen. The corporate tax enjoys the dubious distinction of erring in both directions. Since corporate income is taxed in the first instance to the corporate entity, when it is earned, and again to the stockholders, when it is distributed to them in the form of dividends, while the income of a partnership or a sole proprietorship is taxed but once to the partners or the sole proprietor, the corporate tax discriminates against incorporated partnerships and incorporated sole proprietorships. On the other hand, the recognition of an artificial legal convention as an independent taxable entity is a constant stimulus to tax manipulation and tax avoidance.

The theoretical objections to the present system of taxing the income of close corporations are that it makes the conduct of a business subordinate to tax considerations and interposes an unwarranted impediment to freedom of choice of the form of business organization, because of the double tax on corporate income, as contrasted with the single tax upon the income of a partnership or a sole proprietorship. Moreover, by treating the corporate personality as a distinct taxable entity, the corporate tax serves as a shield behind which the tax dodger may conduct his maneuvers with impunity.

The ultimate test of a tax, however, lies in the practical operation of the tax in a concrete context, rather than its theoretical imperfections. The present system of taxing the income of close corporations must be judged by whether it really does create a genuine obstacle to conducting a business as a corporation rather than a partnership or sole proprietorship, and whether it actually encourages tax manipulation and tax avoidance.

\section{Choice of Form of Business Organization: The Close Corporation versus the} Partinership or Sole Proprietorship

It is difficult to determine the precise extent to which the present system of taxing the income of close corporations constitutes a genuine impediment to the selection of the corporate form to conduct a business, which could be carried on as a partnership or sole proprietorship, because the relative tax advantages and disadvantages of various forms of business organization are linked so intimately with the concrete facts of a particular situation. In some cases it may actually be more economical to do business as a corporation. In others, a partnership or a sole proprietorship is preferable from a tax point of view. Unquestionably, the fact that the income of a close corporation is taxed differently than that of a partnership or a sole proprietorship is a predominating factor in the selection of the form of business organization. It is not, however, a consideration which inclines constantly in the same direction, since the tax advantages of one form of organization over another shift continually with changes in the underlying factual situation.

Because the tax advantages of a particular form of business organization are tied so closely to the unique facts of the particular situation, it is impossible to lay down 
any rigid rule which can be applied indiscriminately in every case to determine the most economical form of doing business from a tax point of view. It is feasible, however, to point out some of the major tax factors which must be weighed in choosing a form of business organization to illustrate the unwarranted predominance which tax considerations have achieved in this area, because of the identification of the corporation as an independent taxable entity.

\section{A. Rates}

A basic consideration in the choice of a corporation or a partnership or sole proprietorship as a form of business organization is the mattter of rates, since corporate income is taxed under a different rate schedule than that applied to individual income, and corporate income is subject to the excess profits tax, which does not apply to other types of income. ${ }^{3}$ There is, however, no constant ratio between the corporate tax and the individual tax, since this depends upon such variant factors as the size of the income, the application of the excess profits tax, and the personal status of the individual taxpayer. The recent revenue acts, which have reimposed the excess profits tax and permitted married taxpayers to split their incomes, have tended to favor partnerships and sole proprietorships, rather than corporations, as a form of business organization. However, the actual rate, at which the income from an enterprise is taxed, depends to such an extent upon the unique facts of the particular situation that it is impossible to generalize about which rates are more favorable.

\section{B. Double Taxation}

An important factor in determining the actual effective rate of tax upon the income of a close corporation is the possibility of avoiding a double tax. If corporate income is taxed first to the corporation, when it is earned, and again to the stockholders, when it is distributed to them in the form of dividends, it is obvious that the aggregate tax upon corporate income will be heavier than that which would be incurred by a partnership or a sole proprietorship. In many cases, however, it is possible to eliminate the double tax. In a given situation it may even be possible to divide the income from an incorporated enterprise between the corporation and the individual entrepreneurs, so that part of the income is taxed to the corporation and part to the individual shareholders, with a lower aggregate tax than if it were all taxed directly to the individual owners of the business.

As a general rule, if the corporate profits can be distributed to the stockholders in a form which is deductible from the corporate income, a business may be conducted as a corporation about as economically from a tax point of view as a partnership, because of the elimination of any additional corporate tax. Thus, many

\footnotetext{
${ }^{3}$ Individual rates range from $\mathbf{2 2 . 2}$ to 92 per cent; corporate rates, including the excess profits tax, from 30 to 82 per cent.

The lowest corporate rate is higher than the highest individual rates in the case of a married person whose net income (before exemptions) is less than $\$ 14,000$, a single person whose net income is less than $\$ 7,000$, and the head of a household whose net income is less than about $\$ 12,000$.
} 
small enterprises, whose earnings are derived chiefly from the efforts of the owners of the business, are able to operate as corporations without any undue tax penalty, because they can distribute their profits in the form of salaries, which are deductible from the corporate income. In fact, if part of the corporate earnings are plowed back into the business for expansion, it may be more economical to operate as a corporation than a partnership. In the case of a partnership, all of the partnership income is taxed to the partners, regardless of whether it is distributed to them or retained in the business. There is, therefore, no opportunity to divide the income from the business between the partners and the firm. In the case of a corporation, however, if part of the corporate income can be distributed to the shareholders in the form of salaries, or other items deductible from the corporate income, and part can be retained in the corporation, it is possible to divide the income from the enterprise between the corporation and the stockholders, so as to take advantage of the lower brackets under both the corporate and individual taxes.

Of course, matters may not work out so neatly. The deduction for salaries is limited to reasonable salaries, or in the words of the statute to "a reasonable allowance for salaries or other compensation for personal services actually rendered." "5 Moreover, there are restrictions upon the earnings which a corporation may retain without encountering the surtax under Section ro2, which is imposed as a penalty upon a corporation" formed or availed of for the purpose of preventing the imposition of the surtax upon its shareholders or the shareholders of any other corporation, though the medium of permitting earnings or profits to accumulate instead of being divided or distributed." The limitation upon the deduction for salaries to reasonable salaries may create an awkward situation, if the particular stockholder needs a greater portion of the earnings of the business than can properly be regarded as reasonable compensation for the services which he renders to the corporation. Furthermore, in order to accumulate earnings in the corporation without incurring the Section I02 surtax, there must be some showing that they are needed for expansion or some independent business purpose of the corporation.

Salaries or compensation for personal services are not the only items which may be deducted from corporate income. Although dividends distributed by a corporation are not deductible in computing the corporate tax, the interest which a corporation pays on its debts is. Consequently, it has become customary to finance a corporation largely with borrowed capital in order to distribute the corporate earnings in the form of interest upon its obligations, which is deductible from the corporate

${ }^{5}$ INT. Rev. CODE $\$ 23$ (a)(I)(A). Section 23 (c) of the Code forbids the deduction of expenses (including salaries) and interest incurred by a corporation on the accrual basis in favor of a stockholder on the cash basis, who owns, directly or indirectly, more than 50 per cent in value of the corporate stock, unless the deductible itcm is paid within the taxable year, or two and one-half months from the close of the taxable year.

'INT. Rev. CODE $\S \mathrm{roz}(\mathrm{a})$.

"For an interesting attempt to appraise the impact of the Section 102 surtax upon the conduct of a business in the corporate form, see Economic EFFECTs of SECTION 102 (195I), a questionnaire and panel investigation conducted under the direction of the panel committee of the Tax Institute, Incorporated. 
income. $^{8}$ Although borrowed capital is treated less favorably than equity capital under the excess profits tax, there are a number of advantages in financing a corporation with borrowed capital, or what is popularly called "thin incorporation." In addition to deducting the interest paid on the obligations of the corporation, it is possible to retain substantial amounts of the corporate earnings in the corporate treasury to fund its indebtedness without incurring the Section 102 surtax. Moreover, the corporation can distribute its earnings by redeeming its bonds, or paying off its debts, without subjecting such payments to an additional tax in the hands of the stockholder-creditors, where a similar distribution in redemption of part of its stock would run the risk of being taxed as an ordinary dividend under Section III $(\mathrm{g}) .^{10}$

While thin incorporation has its advantages, there is a still unsettled problem as to just how thin incorporation can get before the Commissioner can see through it. ${ }^{11}$ It has been held that if the borrowed capital is substantially disproportionate to the equity capital, the borrowed capital will be treated as equity capital and a deduction for interest paid on the borrowed capital will be disallowed. ${ }^{12}$ Moreover there appears to be no manifest reason why the redemption of bonds in such a case could not be taxed under Section $\operatorname{II}_{5}(\mathrm{~g})$ as an ordinary dividend. ${ }^{13}$ It is obvious that while it may be possible to eliminate a corporate tax by paying out corporate earnings in the form of interest rather than dividends, the restrictions on thin incorporations, like

\footnotetext{
${ }^{8}$ In an endeavor to create obligations which from the corporation's point of view have the advantages of stock, but which will be treated taxwise as debts, corporations have resorted to "hybrid securities," which in practice have proved very difficult to classify as stock interests or debts. Sce John Kelley Co. v. Commissioner, 326 U. S. 521 (r946); Wetterau Grocer Co., Inc. v. Commissioner, 179 F. 2 d 158 (8th Cir. I950); Commissioner v. Schmoll Fils Associated, Inc., I ro F. 2d 61 I (2d Cir. 1940); United States v. South Georgia Ry., Io7 F. 2d 3 (5th Cir. 1939); Helvering v. Richmond, F. \& P. R. R., 90 F. 2d 97I (4th Cir. 1937).

"See Schlesinger, "Thin" Incorporations: Income Tax Advantages and Pitfalls, 6r Harv. L. Rev. 50 (1947).

${ }_{10}$ Ordinarily the redemption of stock is treated as a sale of the stock by the stockholder to the corporation, and the stockholder's taxable income is limited to the excess of the redemption price over his basis for the stock. Usually, moreover, any such excess will be taxed as a long-term capital gain. To prevent corporations from distributing their earnings under the guise of a partial liquidation, Section II5 $(\mathrm{g})(\mathrm{I})$ of the Code provides that if a corporation "cancels or redeems its stock ... at such time and in such manner as to make the distribution and cancellation or redemption in whole or in part essentially equivalent to the distribution of a taxable dividend, the amount so distributed" shall be taxed as an ordinary dividend to the extent that it represents a distribution of taxable surplus. It is argued that Section $\operatorname{IIS}_{\mathrm{S}} \mathrm{g}$ )(I) has no application to the payment of debts or the redemption of bonds because it refers in terms to the cancellation or redemption of "stock."

${ }^{11}$ Note, Loan Versus Investment-Inadequate Capitalization, 5 TAx L. Rev. 424 (I950); Bryson, Stockholder Loans: Thin Capitalizations, 8 N. Y. U. TAx INST. 732 (1950); Semmel, Tax Conseguences of Inadequate Capitalization, 48 Cot. L. REv. 202 (1948).

${ }_{12}$ Dobkin v. Commissioner, I92 F. 2d 392 (2d Cir. 195I); Sogg v. Commissioner, 194 F. 2d 540 (6th Cir. 1952); Schnitzer v. Commissioner, r83 F. 2d 70 (9th Cir. 1950); Swoby Corporation v. Commissioner, 9 T. C. 887 (I947); Janeway v. Commissioner, 147 F. 2d 602 (2d Cir. 1945). For cases where there appeared to be a substantial disproportion between equity and borrowed capital, however, and the borrowed capital was still treated as a debt, see Spreckels v. Commissioner, 8 T. C. M. II13 (r949); McDermott v. Commissioner, 13 T. C. 468 (1949) (A).

${ }^{13}$ See Stein v. Commissioner, 46 B. T. A. 135 (I942) where in holding that payments on a note issued by a corporation to its stockholders were taxable to the stockholders as ordinary dividends, the Board suggested Section $115(\mathrm{~g})$ as an alternative ground of decision.
} 
the limitation upon the deduction of salaries, make this a matter calling for skillful and sophisticated tax management.

In addition to the distribution of corporate earnings in the form of salaries and interest to minimize or eliminate the corporate income tax, part of the corporate profits are frequently paid out in the form of rent, which the corporation can deduct from its income as a business expense. Under this scheme, the stockholders will retain title to the property which the corporation needs to operate its business and lease it to the corporation, so that the rent paid by the corporation can be deducted from its income. Here again, however, caution must be exercised. If the rent paid by the corporation is in excess of the fair figure which would have been fixed in an arm's length transaction, the excess above the fair rental value of the property will be disallowed as a deduction. ${ }^{14}$ It seems possible, moreover, that if the lease simply represents a scheme for diverting income from the corporation and serves no independent business purpose of the corporation, any deduction for rent may be disallowed, while the rent itself may be taxed to the stockholder who receives it as a dividend. ${ }^{15}$

\section{Tax-Exempt Income; Capital Gains}

In addition to the effective rates of tax upon the income of an enterprise conducted as a corporation and as a partnership, there are other differences between the ways in which corporations and partnerships are taxed, which follow as more or less logical corollaries from the recognition of the corporation as a distinct taxable entity, and which must be taken into account in the choice of a form of business organization. One of these differences, for example, is the way in which tax-exempt income of a corporation and of a partnership is treated.

Tax-exempt income of a partnership does not lose its tax-exempt status when it is taxed to the partners, since the partnership is merely a conduit for allocating the partnership income to the partners. Tax-exempt income of a corporation, however, is transmuted into taxable income when it passes through the hands of the corporation and is distributed in the form of dividends, since the exemption is lost by the interposition of an independent taxable entity between the income and the stockholders. ${ }^{16}$ The moral, of course, is plain. Tax-exempt or partially tax-exempt income should

${ }^{14}$ INr. Rev. Code $\$ 45 ;$ U. S. Treas. Reg. III, \$29.45-I. See Welworth Realty Co. v. Commissioner, 40 B. T. A. 97 (1939) (A).

${ }^{16}$ In 58 th Street Plaza Theatre, Inc., I6 T. C. 469 (195x), affd, 195 F. $2 d 724$ (2d Cir. I952), a family corporation, which owned a valuable lease on a motion picture theater, sub-leased the theater to a minority stockholder, the wife of the majority stockholder, who proceeded to hire her husband to operate the theater for her. The court found that this arrangement was simply designed to divert income from the corporation to reduce taxes and served no independent business purpose of the corporation, and held that the profits from the operation of the theater were taxable to the corporation as a part of its income and also to the wife as a dividend. Incidentally where property is leased by a corporation to a stockholder (as distinguished from a lease by a stockholder to the corporation) in addition to the risk that the transaction may not stand up taxwise, the rent received from the stockholder will be personal holding company income, if the stockholder owns directly or indirectly 25 per cent or more of the corporate stock, and may subject the corporation to the personal holding company surtax.

${ }^{18}$ U. S. Treas. Reg. III, \$29.I15-3; Charles F. Ayer v. Commissioner, I2 B. T. A. 284 (I928). 
not be given to a corporation, but should, as far as practicable, be retained by the individual stockholders.

The fact that income may change its character between the time it is earned by a corporation and distributed to the stockholders does not, however, always work to the disadvantage of the stockholders. It is sometimes possible to convert ordinary income of a corporation into a long-term capital gain in the hands of a stockholder by liquidating the corporation. Incidentally, however, there is no profit in transferring capital assets, which have increased in value, to a corporation with the idea of having the corporation sell the assets and realize the gain, since the minimum tax which a corporation must pay upon such a gain is 26 per cent, which is the maximum tax which an individual may pay, and he may pay less. ${ }^{17}$ Moreover, if the gain realized by the corporation is ultimately distributed to the stockholder it will be taxed to him again, and, unless the distribution occurs in connection with a liquidation of the corporation, taxed as ordinary income.

\section{Deferring Gains and Losses}

One of the advantages of conducting an expanding business as a corporation, which was noted earlier, is that the earnings which are retained by the corporation may be kept out of the incomes of the stockholders and taxed to the corporation in a lower bracket than they would be taxed to the stockholders. In other words, this is a possible way of dividing the income of a business between the corporation and the proprietors of the business and taking advantage of the lower brackets of both the corporate and individual taxes. On the other hand, if a business is conducted as a partnership or a sole proprietorship, all of the income of the business will be taxed to the partners or to the sole proprietor, regardless of whether it is actually distributed to them or plowed back into the business.

Conversely, however, it may be advantageous to organize a new business, in which losses are anticipated in the early years, as a partnership or sole proprietorship, rather than a corporation, since the losses incurred in starting the business can be utilized directly by the partners or the sole proprietor to offset their gains from other sources, and if they arise from the operation of the business, as distinguished from the sale or exchange of capital assets, they will be fully deductible as ordinary business losses. If, on the other hand, the business is conducted as a corporation, any losses incurred in the operation of the business will be the losses of the corporation and cannot be availed of by the stockholders. Although such losses may give rise to a net operating loss which can be carried over and offset against the profits of later years, if the corporation continues to be unsuccessful and realizes no gains the carry-over cannot be utilized either by the corporation or the stockholders. Moreover, although the stockholders will realize a loss when the corporation is finally

\footnotetext{
${ }^{17}$ Long-term capital gains realized by a corporation are taxed at 26 per cent. The tax on a long-term capital gain in the case of an individual cannot exceed 26 per cent. If, however, it will result in a lower tax, an individual may pay a tax on 50 per cent of the gain at the regular rates, so conceivably the individual tax on a long-term capital gain may be as low as 50 per cent of 22.2 per cent (the lowest individual bracket) or II.I per cent.
} 
liquidated, the loss will ordinarily take the form of a long-term capital loss subject to the restrictions on such losses.

\section{E. Organization and Liquidation}

Although theoretically a corporation should pay a heavier tax than a partnership or a sole proprietorship, because corporate income is exposed to the hazard of a double tax, actually the tax burden of a close corporation depends upon a number of adventitious circumstances. Moreover, the circumstances which determine the relative tax advantages of doing business under the corporate form are not static but are subject to constant fluctuation. At one stage in the existence of a business, it may be profitable to operate as a corporation, and at another, as a partnership or sole proprietorship. Not only changes in the fortunes of the business, but changes in the law, such as the enactment or repeal of an excess profits tax, permission for married taxpayers to split their incomes, and upward and downward revisions in the corporate and individual rate schedules, may make a change in the form of business organization imperative. In this connection it is important to bear in mind that it is much easier to shift into a corporation than it is to shift out of one.

A partnership can be organized or liquidated without realizing taxable gain or loss. ${ }^{18}$ Moreover, a partnership can be converted into a corporation without incurring any gain or loss, if the partners are in control of the corporation after the transfer of the partnership assets to the corporation, and they retain the same proportionate interests in the corporation, which they had in the partnership property. ${ }^{19}$

${ }^{1 *}$ No gain or loss is recognized on the organization of a partnership, but any property contributed by the partners takes as its basis, in the hands of the partnership, the basis which it had in the hands of the contributing partner. INT. REv. CODE $\$ I_{5}\left(I_{3}\right)$. When a partnership dissolves and distributes property to the partners, no gain or loss is realized, but the basis of the property in the hands of a partner is a proportionate part of the basis for his interest in the partnership. Ibid. If the partnership distributes cash this reduces the basis of the partners' interests in the partnership, but taxable gain will not be realized by the partners unless the cash distributed exceeds the basis of their partnership interests. The realization of any gain upon the dissolution of a partnership can ordinarily be avoided by having the partnership distribute any cash it may have on hand first, and then its other assets. Unless the cash exceeds the basis of the partners' interests, it will simply reduce the basis of their interests, and upon the distribution of the partnership's other assets, the remaining basis of the partners' interests will be allocated among them and there will be no taxable gain.

${ }^{10}$ INT. Rev. CODE $\oint_{112}(b)(5)$. Gain or loss is not realized where property is transfererd to a controlled corporation solely in exchange for stock or securities in the corporation, and, if the transfer is by two or more persons, the amount of stock or securities received by them is substantially in proportion to their interests in the transferred property prior to the transfer. "Control" is defined as "the ownership of stock possessing at least 80 per centum of the total combined voting power of all classes of stock entitled to vote and at least 80 per centum of the total number of shares of all other classes of stock of the corporation." INT. REV. CODE $\$ I I 2(h)$.

Since in the case of a tax-free incorporation, the stock or securities in the hands of the transferor takes as its basis the basis of the transferred property and the assets transferred to the corporation have the same basis to the corporation which they had in the hands of the transferor, it is sometimes profitable to make a taxable, rather than a tax-free, transfer to the corporation. For example, suppose that $A$ and $B$ are partners who own a patent which has 20 years to run, whose fair market value is \$roo,000, and whose basis to $A$ and $B$ is zero. If they transfer the patent to a corporation by a tax-free transfer, they will realize no income, but the corporation cannot deduct any amortization in connection with the patent, since it has a zero basis. If, however, $A$ and $B$ make a taxable transfer to the corporation for $\$ 100,000$ in cash, or stock or securities, worth $\$ 100,000$, they will realize a taxable gain of \$100,000. Assuming, however, that the gain is taxed as a long-term capital gain under section $\operatorname{IIF}(\mathrm{j})$ of the Code, the maximum tax on the gain will be at 26 per cent or $\$ 26,000$. The patent now has 
The recognition of the corporation as a distinct taxable entity, however, usually makes it impossible to liquidate a corporation and shift to a partnership without serious tax consequences. A common situation which frequently causes embarrassment in this connection is where it becomes necessary to liquidate an incorporated business which has built up a substantial good will. To take a typical case, suppose that $A$ and $B$ each invested $\$ 50,000$ in a soft drink business, which they operated as partners. The business was unusually successful and they decided to incorporate it, which they did by transferring the partnership assets to a newly organized corporation in exchange for all of its stock. Later an excess profits tax was passed, and $A$ and $B$ discovered that they could only withdraw a fraction of the corporate earnings, which they needed to live in the style to which they had become accustomed, as reasonable salaries which were deductible from the corporate income. It became apparent that the cost of doing business as a corporation was prohibitive, so $A$ and $B$ decided to liquidate the corporation and re-convert to a partnership. They had the corporation redeem their stock in exchange for the corporate assets, which they proceeded to convey to a partnership. Everything went smoothly until the tax collector stepped in and decided that the value of the business was $\$ \mathrm{x}, 000,000$, allowing $\$ 900,000$ for good will, and that $A$ and $B$ had realized a capital gain of $\$ 900,000$ when they exchanged their stock (which had a basis of $\$ 100,000$, their original investment) for the corporate assets, on which the minimum tax was $\$ 234,000$.

Of course, the fact that gain or loss is recognized when a corporation liquidates may work to the advantage of the taxpayer. For example, suppose that a corporation has an inventory which it purchased for $\$ 50,000$ and which has a fair market value of $\$ x 00,000$. If the corporation continues in business and sells the merchandise in its inventory it will realize ordinary income of $\$ 50,000$ upon which the tax might be as high as 82 per cent or $\$ 4 x, 000$. If, however, the corporation liquidates and distributes its inventory to redeem stock having a basis of $\$ 50,000$, the stockholders will realize a long-term capital gain of $\$ 50,000$, on which the maximum tax will be

a basis of $\$ 100,000$ in the hands of the corporation, which can deduct that sum by way of depreciation over a ro year period. Assuming a corporate tax of 82 per cent there is a net saving of $\$ 56,000$. In this connection, it is important to notice, however, that the 1951 Act provides that gains from sales or exchanges of depreciable property between an individual and a corporation, in which he or his spousc, minor children, or minor grandchildren own more than 80 per cent in value of the outstanding stock, shall be taxed as ordinary income. INT. REv. CODE $\S I_{17}(0)$, added by $\$ 328,1951$ Act. Consequently, in the hypothetical case, if $A$ and $B$ were husband and wife, or father and minor son, who together owned more than 80 per cent of the stock in the corporation to which they made a taxable transfer of the patent, the gain from the transfer would be fully taxable as ordinary income. If, however, $A$ and $B$ wcre brothers and neither one owned more than 80 per cent of the stock of the corporation, their gain upon the transfer would still be taxable as a long-term capital gain.

A partnership may be incorporated tax-free either by having the partnership transfer its assets to the corporation in return for its stock and securities, which the partnership then distributes to the partncrs, or by having the partnership dissolve and distribute its assets to the partners, who then transfer the assets to the corporation. The form which is followed may have an important effect on the basis of the assets in the hands of the corporation, since any assets transferred directly by the partnership to the corporation will take as their basis in the hands of the corporation, the basis which they had in the hands of the partnership; while assets distributed first to the partners and transferred by the partners to the corporation, will take as their basis a proportionate part of the basis of the partners' interests in the partnership. 
26 per cent or $\$ 13,000$. However, the inventory in the stockholders' hands will have a stepped up basis of $\$ 100,000$ so they can transfer the property to a partnership, which can sell it for $\$ 100,000$ without realizing any further gain.

Some other difficulties may be encountered in connection with the liquidation of a corporation which do not occur upon the dissolution of a partnership. If the owners of a corporation wish to sell the corporate assets, which have appreciated in value, the proper procedure is to liquidate the corporation and distribute the assets to the stockholders and have the stockholders sell the assets, instead of having the corporation sell its assets and distribute the proceeds of the sale to the stockholders. If the sale is consumated by the corporation, the corporation will realize a gain from the sale which will be taxed to the corporation, and the stockholders will have additional taxable income when the proceeds of the sale are distributed to them. Theoretically, however, if the assets are distributed to the stockholders who make the sale, the only taxable gain, which will be incurred, will be a long-term capital gain (the difference between the fair market value of the assets distributed to the stockholders by the corporation and the basis of their stock) at the time the assets are distributed to the stockholders. In the hands of the stockholders, the corporate assets will take as their basis the fair market value of the assets at the date of distribution, and since presumably this will approximate the figure at which the assets are sold by the stockholders, no further gain will be realized on the sale. In this connection, however, the Treasury has manifested a stubborn inclination to regard the stockholders as the agents of the corporation in selling the corporate assets and to treat the sale by the stockholders as a sale by a corporation and a distribution of the proceeds of the sale to the stockholders. The Treasury has some judicial backing for its position and the cases are inconclusive and unsatisfactory. ${ }^{20}$ This is, of course, a problem which does not arise in the case of a partnership, where there will be only a single tax regardless of whether the partnership sells its assets and distributes the proceeds to the partners or distributes its assets to the partners who sell them. ${ }^{21}$

The moral is plain. It is wise to proceed with caution in incorporating a business. Before the decision to incorporate is made, the possible tax consequences if it be-

${ }^{20}$ Compare the decisions of the Supreme Court in Commissioner v. Court Holding Co., 324 U. S. 331 (1945) and United States v. Cumberland Public Service Co., 338 U. S. 45 I (1950). See Gutkin and Beck, Sale of Assets Received on Liquidation, 28 TAXES 328 (1950); Note, Sale of Stock or Purchase of Assets, 4 TAX L. Rev. 378 (1949); Seghers, Purchase and Sale of a Business or Its Assets, 26 TAxEs II65 (1948); Magill, Sale of Corporate Stock or Assets, 47 CoL. L. Rivv. 707 (I947).

${ }_{21}$ Where a partnership sells only part of its assets, however, it may make a considerable difference taxwise whether the assets are sold directly by the partnership, or are distributed to the partners and sold by the partners, because of the effect on the basis of the assets. For example, suppose that $A$ and $B$ organize $A B$ company, each contributing $\$ 50,000$ which remains the basis for their respective interests in the partnership. $A B$ company purchases $\mathrm{r}, 000$ shares of $X$ Corporation stock for $\$ 50,000$ which increase in value to $\$ 100,000$. Assuming that the fair market value of all $A B$ company's assets are $\$ 150,000$, if the partnership sells the $X$ stock for $\$ 100,000$ the partners will realize a capital gain of $\$ 50,000$, or $\$ 25,000$ apiece. If, however, the $X$ stock is distributed to the partners and sold by the partners for $\$ r 00,000$ their taxable gain will only be $\$ 33,333.00$ or $\$ 16,666.67$ each, since the basis of the stock in their hands would be $\$ 66,666.67\left(\frac{\text { roo,000 } x \text { roo,000 }}{150,000}\right)$. 
comes necessary to liquidate later should be carefully considered. Incidentally, incorporation has a fatal fascination for the average lawyer who is not versed in tax matters. Incorporation should not be undertaken without consulting a tax expert and carefully mulling over the possible tax consequences, not only in the immediate future, but at some more distant time when changes in the business or the tax law may make it desirable to shed the corporate form. ${ }^{22}$

\section{F. Some Miscellaneous Considerations}

In choosing a form of business organization, there are a number of minor tax considerations, which, although seldom controlling, operate as make-weights in a final decision. In this connection, state as well as federal taxes must be taken into account. Ordinarily, a corporation pays a franchise tax for the privilege of doing business in the corporate form, to which a partnership is not subject. ${ }^{23}$ Moreover, there is usually a fee for incorporation, which does not apply to a partnership, as well as various taxes upon the issuance and transfer of stock, which have no application to a partnership. Although the costs of incorporating a small corporation are usually nominal, they are factors to be weighed in the balance of a final judgment.

The excess profits tax, which may or may not have lapsed before this article is published, applies to corporations, but not to partnerships or sole proprietorships. Moreover, since the stockholders who work for a corporation are treated as employees of the corporation, while working partners are regarded as proprietors, there are differences in social security taxes between a partnership and a corporation. ${ }^{24}$

22 The principal purpose of this brief discussion of organization and liquidation of a business has been to illustrate the arbitrary impact of the conception of the corporation as a distinct taxable entity upon the taxation of close corporations and partnerships. Some technical considerations which have not been considered because their inclusion in a discussion of this type scarcely seemed to warrant the detail involved, are the effect of switching from one form of business organization to another upon ( $I$ ) the credit for the excess profits tax and the excess profits tax ceiling on new businesses; (2) carryover and carry backs of net operating losses; (3) the disallowance of deductions; (4) bunching income in a single taxable period; and (5) the transfer of life insurance policies. Moreover, no consideration has been given to the selection of a taxable year for a new form of business organization and whether it is wiser to liquidate during or at the end of a taxable year.

${ }^{23}$ However, some states impose taxes on unincorporated business as well as corporations. On the other hand, some states have a corporate income tax, but no individual income tax. Morcover, a corporation which seeks to do business outside the state of its incorporation may have to qualify or incorporate in the foreign state, where it seeks to do business, while there is usually no similar requirement in connection with a partnership. The effect of state taxes upon the form of business organization may be neutralized to some extent, however, by the fact that they are deductible from the federal income tax.

24 The tax for old age benefits in the case of the stockholder employec is 3 per cent of his salary (up to $\$ 3,600$ ), which takes the form of a payroll tax of 1.5 per cent and a tax on wages of 1.5 per cent. Moreover, the stockholder-employee's salary (up to $\$ 3,000$ ) is subject to a 3 per cont payroll tax for unemployment insurance, which may, however, be reduced by merit-rating. Consequently, the social security taxes of the stockholder employee may amount to $\$ 198$ annually (3 per cent of $\$ 3,600$, plus 3 per cent of $\$ 3,000$ ).

Since a partner is not an employee of a partnership for social security tax purposes, he pays no tax for unemployment insurance and his tax for an old age benefits is limited to $2 \frac{1}{2}$ per cent of his income up to $\$ 3,600$ or $\$ 81$ a year.

Perhaps the most significant consideration with respect to social security taxes in choosing a form of business organization is that since a partner is not an employee of the partncrship, a business con. ducted as a partnership, which has only seven employees besides the working partners, will not be subject to a tax for unemployment insurance, which is only imposed where there are eight or more employces. 
However, the fact that a stockholder may be an employee of a corporation, while a partner cannot, at least for tax purposes, be an employee of the partnership, makes it possible to set up a qualified profit sharing, stock bonus, or pension plan in connection with a corporation by which the owners of the corporate business can defer income until after their retirement, which is not feasible in connection with the partners in a partnership. ${ }^{25}$

Although it may be possible to operate a business as a corporation as economically, or even more economically, ${ }^{26}$ from a tax point of view, as a partnership or a sole proprietorship, it is clear that this depends upon adventitious circumstances of the particular situation. The law itself does very little to equalize the tax burdens of incorporated and unincorporated businesses. If there is any parity, it is only because taxpayers are shrewd and sophisticated enough to manipulate the law to reach this result. Here, as in so many other areas of federal tax law, one is constantly confronted with the distressing spectacle of a battle of wits, where the ultimate tax burden depends, not upon the taxpayer's economic situation, but upon his skill in circumventing the tax collector. This is an unhealthy situation which is directly attributable to the recognition of the corporation as a distinct taxable entity, and conforming the corporate tax to legal conventions rather than economic realities. If the present system of taxing close corporations is an inevitable administrative necessity, there is nothing to do except endure it. If, however, it is feasible to devise some more equitable system, the case for revision seems established.

\section{The Corporation and Tax Avoidance}

The theoretical objections to the present system of taxing the income of close corporations are that the recognition of the corporation as a distinct taxable entity constitutes an unwarranted impediment to doing business in the corporate form and an active inducement to tax manipulation and avoidance. In order to bring these objections into sharper focus, it is convenient to postulate two distinct types of factual situations. In one, the assumption is that there is a group of lily white associates, who are seeking to conduct an enterprise for some legitimate business reason, which has no connection with tax avoidance, without incurring a tax penalty which would put them at a competitive disadvantage with unincorporated businesses. The other

On the other hand, if the business is conducted as a corporation and one or more of the stockholders (in addition to the seven non-stockholder employees) work for the corporation, it will be subject to the tax for unemployment insurance.

${ }^{25}$ To qualify for tax benefits such plans must be confined to employees. A stockholder-employee may be covered by such a plan, but a working partner, since he is not technically an employee of the partnership, may not.

${ }_{20} \mathrm{~A}$ minor advantage which the corporation enjoys over the unincorporated business is that sole proprietors and partners must pay their income taxes currently as the income is ea:ned, while the corporation does not have to pay until after the close of the taxable year. Formerly a corporation could pay its tax in four quarterly installments in the year after the close of the taxable year, so the corporation could retain the money needed to meet the tax for a year longer than an individual. Under the $195^{\circ}$ Act the privilege of paying the corporate tax in four installments is being gradually withdrawn, so that after December $3 \mathrm{r}$, 1954, corporations must pay their taxes in two equal installments, one of which, in the case of a calendar year taxpayer, will be due on March 15 and the other on June I5. INT. REv. Cone $\$ 56($ b) (2), as amended by $\$ 205$, I950 Act. 
situation assumes a black hearted rascal, who resorts to a corporation, not because he has any independent business reason for conducting his affairs in the corporate form, but solely to dodge his fair share of the tax burden.

The dichotomy is, of course, entirely unreal. It is offered simply as a convenient hypothesis for analyzing the principal objections to the corporate tax. Doubtless there are cases where a corporation is resorted to without any thought of tax avoidance as a logical way to organize a business, and any subsequent tax maneuvering is purely defensive to avoid the unfair burden of a double tax. At the other extreme, there are situations where a taxpayer uses a corporation, although it is an unnatural and awkward way of arranging his affairs, purely from tax avoidance motives. Most cases, however, fall somewhere between the extremes, and the corporate form is adopted both because it is a convenient way of doing business and because it offers certain tax advantages.

The classification of the operational characteristics of the corporate tax under the headings of the use of the corporation as a method of carrying on a business and the use of the corporation as a medium for tax avoidance is even more arbitrary than the factual assumptions that the corporation is resorted to exclusively for one or the other purpose. Thus, for example, although paying out corporate profits in the form of reasonable salaries in order to eliminate the corporate tax might fairly be characterized as a defensive maneuver designed to neutralize the unfair burden which the corporate tax imposes on incorporated partnerships and proprietorships, resort to the corporate form in order to get a lower rate of tax upon the profits retained in the business in the case of an expanding enterprise clearly envisages a tax advantage denied unincorporated businesses and savors of tax avoidance. The classification of the operational characteristics of the corporate tax, like the factual assumptions which furnish the basis for the classification, is a matter of convenience rather than strict analytical affinity. The aspects of the tax discussed in connection with the use of the corporation as a method of carrying on business appear in that context simply because it is a convenient place to consider them. The same thing is true of the aspects of the tax considered in connection with the use of the corporation as a method of tax avoidance. Some of the quirks of the corporate tax operate to ease the discrimination between incorporated and unincorporated businesses, while others are calculated to enable a taxpayer to escape his fair share of the tax burden. However, the classification of these characteristics in this paper is purely a matter of descriptive convenience. It involves neither logical coherence, nor tacit moral judgment.

It is difficult to appraise the precise amount of tax avoidance attributable to the current system of taxing the income from close corporations, because there is no solid statistical data to determine how the tax actually operates on a practical level. The recognition of the corporation as an independent taxable entity constitutes a wide open invitation to tax manipulation, because it affords an opportunity to try out practically every type of tax avoidance. Congress has, however, been more at- 
tentive to the loopholes in the corporate tax than it has to the possibilities of discrimination against incorporated business due to the double tax, and the courts have struggled valiantly to plug up any loopholes which Congress may have missed, even to the point of plugging up loopholes where no loophole existed. ${ }^{27}$ The over-all pattern of the corporate tax presents a curiously futile competition between a basically unsound tax and a frenzied patchwork of provisions designed to cure the ills created by an initially erroneous approach. By recognizing the close corporation as an independent taxable entity, Congress gave impetus to a vast number of tax dodges, which it has been trying to outlaw ever since. Upon the violent assumption that the safeguards against tax avoidance which have been written into the corporation tax are actually effective, it still seems that it would have been simpler to adopt a tax predicated upon economic realities which would not have lent itself to tax avoidance, instead of starting with a postulate which is a positive inducement to tax avoidance and then trying to suppress these maneuvers.

\section{A. Incorporated Pocketbooks}

Perhaps, the most obvious type of tax avoidance fostered by the recognition of the corporation as an independent taxable entity is the so called" incorporated pocketbook." When corporate rates are low in comparison with individual rates, a wealthy individual may incorporate his estate to realize his income in the form of corporate income taxable at the lower corporate rates. This is known as an incorporated pocketbook. For example, the law provides that dividends received by a corporation from a domestic corporation ${ }^{28}$ and certain foreign corporations, which are subject to the federal income tax, ${ }^{29}$ may be credited against net income of the stockholder corporation to the extent of 85 per cent of the dividends, to compensate for the corporate tax to which the income represented by the dividends was subjected in the hands of the distributing corporation. Moreover, such dividends are not subject to the excess profits tax. ${ }^{30}$ This means that only 5 per cent of an intercorporate dividend is subject to the corporate income tax, or to restate the matter from another angle, dividends received by a corporation are only

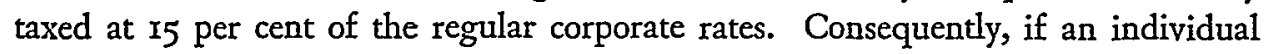
could put his stock holdings in an incorporated pocketbook, whose net income did not exceed $\$ 25,000$, the dividends received by the incorporated pocketbook would only be taxed at $x_{5}$ per cent of $3^{0}$ per cent (the rate for corporations whose income does not exceed $\$ 25,000$ ) or 4.5 per cent.

As early as the Igr3 Act, which was the first of the modern federal income tax acts adopted after the ratification of the Sixteenth Amendment, Congress recognized the incorporated pocketbook as an inevitable corollary of the identification of the corporation as an independent taxable entity, and attempted to set up appropriate safeguards. In order to work an incorporated pocketbook successfully, it is necessary

\footnotetext{
${ }^{27}$ Commissioner v. Court Holding Co., 324 U. S. $33 x$ (1945). See note 20 supra.

${ }^{28}$ INT. REv. CODE $\$ 26(b)(1)$.

${ }^{30}$ Id. $\$ 433(\mathrm{a})(\mathrm{I})(\mathrm{A})$. 
not only to divert income to a corporation, but to retain the income in the corporation in order to avoid a tax upon the individual stockholders. Congress seized upon the accumulation of the corporate earnings as the vulnerable spot at which to strike incorporated pocketbooks by imposing a penalty tax upon a corporation formed or availed of for the purpose of avoiding individual surtaxes upon its stockholders by accumulating earnings beyond the reasonable needs of the corporate business. At first the tax took the form of taxing the shareholders upon their distributive shares of the corporate income. ${ }^{31}$ The I92I Act changed the tax to an additional tax upon the corporate income, ${ }^{32}$ and in this form it persists to the present day under the peculiarly non-committal title of the Section Io2 surtax. ${ }^{33}$

As a practical matter the Section 102 surtax has done little to check the rise of incorporated pocketbooks. The weakness of the tax lies in the fact that it is a penalty tax whose application is subject to the difficulties of proving that a corporation has accumulated surplus beyond the reasonable needs of the corporate business for the purpose of avoiding individual surtaxes upon its stockholders. Incorporated pocketbooks continued to flourish under the Section I02 surtax until they reached the dimensions of a national scandal. Hollywood, which frequently takes the lead in tax fashions, produced some of the most bizarre examples of incorporated pocketbooks. It became almost standard practice for a cinema star to form a corporation to which he would sell the right to his services for a modest amount, in order that the corporation could in turn sell the star's services to the producer and convert his salary into corporate income taxable at the lower corporate rates.

A good many incorporated pocketbooks might have been put out of business by the old fashioned device of disregarding the corporate entity. When a motion picture actor formed a corporation to sell his services, it would have required no great degree of judicial perspicacity to penetrate the corporate disguise and tax the compensation for the star's services directly to the star. If a lawyer cannot divert part of his fees to his wife by an agreement that any income earned during their marriage shall belong to them equally, ${ }^{34}$ it is difficult to see why a cinema actor should be allowed to divert his income to a corporation through the crude fiction of selling the right to his services to a corporation and having the corporation sell his services

\footnotetext{
${ }^{31}$ Act of Oct. 3, 1913, 6. 16, 38 Stat. I14, 166-167; Revenue Act of 1918, c. 18, 40 Stat. 1057, 1072.

32 Revenue Act of I921, c. 136, 42 STAT. 227, 247-248.

${ }^{33}$ The rates of the tax are $271 / 2$ per cent of the first $\$ 100,000$ of the corporation's undistributed net income, and $38 \frac{1}{2}$ per cent of the balance in excess of that amount. Although the tax is in addition to the other taxes on corporate income, it is not necessarily a deterrent to accumulating profits in a corporation to avoid individual surtaxes. It may be cheaper for a stockholder in a very high bracket to leave carnings in the corporation and pay the penalty tax, than to distribute them as dividends and incur the individual tax.

${ }^{34}$ Lucus v. Earl, 28 I U. S. III (1930). See also Jones v. Page, ro2 F. 2d 144 (5th Cir. 1939), ccrt. denied, 308 U. S. 562 (1939), where a taxpayer sold the right to his serviecs to his father, who in turn sold them to a motion picture producer, and the court held that the amount paid by the produccr was taxable to the taxpayer, who performed the services, declaring (p. 145): "The conclusion is inescapable that he used his father simply as a conduit in an attempt to reduce or avoid taxes that would . be otherwise assessable against compensation derived from his own personal services."
} 
to the producer. The courts were, perhaps, tending in this direction ${ }^{35}$ when Congress stepped in to supply its own solution through the surtax on personal holding companies. $^{36}$

The surtax on personal holding companies, which was adopted as a more effective deterrent to incorporated pocketbooks than the Section 102 surtax, is a complicated piece of legislation. The basic idea is, however, that the type of corporation which appears most likely to be used as an incorporated pocketbook is called a personal holding company and a prohibitive surtax ${ }^{37}$ (in addition to the regular corporate $\operatorname{tax}^{38}$ ) is imposed upon such organizations. The personal holding company surtax is effective in the narrow area in which it operates, like the corporation formed by the Hollywood actor. The rates of the tax are sufficiently stringent to discouragé effectively personal holding companies and the tax applies automatically to corporations falling within this category, without proof that they are being used to accumulate unreasonably surplus for the purpose of avoiding individual surtaxes. The weakness of the tax, however, lies in its very definiteness and rigidity. In order to qualify as a personal holding company, a corporation must meet certain detailed statutory specifications with regard to stock ownership and the character of its income. $^{30}$ By diversifying the ownership of the corporation or the character of its income, it is relatively easy to sidestep the tax. As a matter of fact, the personal holding company surtax is more of a trap for the unwary individual who unconsciously drifts into a personal holding company situation, than it is a snare for the sophisticated tax avoider who is careful to guard against it.

An incorporated pocketbook, which escapes the personal holding company surtax, may still encounter the Section ro2 surtax. Like the personal holding company surtax, however, the Section I02 surtax is less effective as a snare for the shrewd tax avoider, who always has a list of unassailable alibis for accumulating corporate surplus at his finger tips, than it is as a threat dangling over the head of the innocent corporation, which lives in constant terror of a Section I02 penalty whenever it fails to distribute the last penny of its profits. ${ }^{40}$

Probably the finest flowering of the incorporated pocketbook was the foreign personal holding company. A wealthy taxpayer would organize a corporation in

${ }^{35}$ Cf. Commissioner v. Laughton, II3 F. $2 \mathrm{~d}$ 103 (9th Cir. 1940).

${ }^{30}$ INT. REv. CoDE $\$ \$ 500-506$. The personal holding company surtax first made its appearance in the 1934 Act. In 1937 the tax was rewritten in substantially its present form to catch many of the more blatant devices like the Hollywood corporation which escaped the earlier law.

${ }^{37}$ The rates of the tax are 75 per cent of the first $\$ 2,000$ of the corporation's undistributed net incomc, and 85 per cent of the balance.

${ }^{38} \mathrm{~A}$ personal holding company is not subject, however, to the Section ro2 surtax.

${ }^{30} \mathrm{~A}$ corporation is not classified as a personal holding company unless 80 per cent or more (in some cases this is reduced to 70 per cent) of its gross income is personal holding company income, and more than 50 per cent of its outstanding stock is owned directly or indirectly by not more than five individuals. Personal holding company income includes, with certain exceptions, dividends, annuities, interest, royalties, gains from stock, security and commodity transactions, rents, and income from trusts and estates, personal service contracts, and use of property by a shareholder. Indirect ownership of stock includes ownership of stock owned by a member of an individual's family, or a corporation, partnership, or trust in which he owns an interest.

${ }^{\Delta 0}$ See note 7 supra. 
Bermuda, or some foreign country where income taxes were low or non-existent, and accumulate his income in the corporation in order to remove it from the taxable jurisdiction of the United States. Congress struck at foreign personal holding companies with special legislation, ${ }^{41}$ the most interesting aspect of which is that it disregards the corporate entity and taxes United States shareholders directly upon their distributive shares of the corporation's income.

The Section I02 surtax along with the surtaxes upon domestic and foreign personal holding companies have certainly made the life of the incorporated pocketbook more exciting and evoked new heights of skillful and sophisticated tax planning. It is doubtul whether they have put an end to the device entirely. In the absence of actual statistical data, it is difficult to estimate the gap between theory and practice. There is little reason to doubt the existence of a substantial gap, however, or that refined versions of the incorporated pocketbook are operating successfully today.

\section{B. Splitting Income}

A basic principle for avoiding a progressive tax is to divide a large income taxable in the higher brackets into smaller incomes taxable in lower brackets. The recognition of the corporation as an independent taxable entity is especially well adapted to this process. The simplest way to split up an income taxable in a high bracket into smaller incomes taxable in lower brackets is to make a complete and irrevocable gift of income producing property. This has, however, the practical disadvantage of requiring the taxpayer to sacrifice income and the property which produces the income. One of the most appealing ways, therefore, to split income, is to transfer income producing property to a corporation controlled by the taxpayer, since this offers the opportunity of diverting income to a distinct taxable entity, without losing the substantial ownership of the income, or the property which produces it.

There are various ways of dividing income through the medium of a corporation. One method, which was mentioned earlier, is to transfer a business to a corporation and distribute part of the corporate earnings to the stockholders in the form of salaries, interest or rents, so that part of the income is taxed to the stockholders, while the balance of the corporate profits are retained in the corporate treasury and taxed to the corporation.

The tax upon the income retained by the corporation may be further reduced by splitting up the corporate business among several corporations so as to avoid the excess profits tax and take advantage of the lower brackets of the corporate tax. The desirable level at which to hold corporate income is $\$ 25,000$, since the corporate surtax starts at this point and every corporation is allowed a minimum excess profits tax credit of that amount. ${ }^{42}$ Where the income of a business is divided among

12 INT. Rev. CODE $\$ \$ 33$ I-340.

12 The tax on the first $\$ 25,000$ of corporate income is 30 per cent. Any amount in excess of $\$ 25,000$ is taxed at 52 per cent. If the corporation is subject to the excess profits tax its income over $\$ 25,000$ may be taxed at 82 per cent. 
several corporations (or for that matter between a corporation and a partnership or a sole proprietorship), there is an ever present danger that the division will be disallowed for tax purposes and the entire income from the enterprise taxed to a single entity. ${ }^{43}$ Usually, however, the division of corporate income will stand up for tax purposes, if the division is a natural division of the business, or there is some independent business reason, apart from tax avoidance, for the division. ${ }^{44}$

A corporation may afford a convenient medium for splitting up an income from a business through gifts of stock in the corporation. With the recent relaxation of the rules for taxing the income from family partnerships ${ }^{45}$ and permission to husbands and wives to split their incomes, ${ }^{46}$ there is less pressure for resorting to a corporation to divide an income among a family group. In the past, however, one of the ways of dividing an income from a business among the members of a family was to incorporate the business and distribute the stock in the corporation among the family group. So far no doctrine of a family corporation, analogous to the family partnership doctrine, has developed to tax the income from the business to the original proprietor, ${ }^{47}$ although the division of the income may be ignored, if the donees do not get a real stock ownership in the corporation and the whole arrangement is a patent sham. ${ }^{48}$

\section{Acquisitions of Deficit Corporations}

During World War II the practice grew up of a profitable corporation purchasing a deficit or "shell" corporation, in order to take advantage of an excess profits tax credit, a net operating loss carry-over, or a high basis for depreciable assets

${ }^{4}$ INT. REv. CODE $\S_{45}$ authorizes the Commissioner in the case of "two or more organizations, trades or businesses... owned or controlled directly or indirectly by the same interests ... to distribute, apportion, or allocate gross income, deductions, credits, or allowances between or among such organizations, trades, or businesses, if he determines that such distribution, apportionment, or allocation is necessary in order to prevent evasion of taxes or clearly to reflect the income of any such organization, trades, or businesses." Frequently, when the Commissioner seeks to re-allocate the income of several entities owned by the same interests, he invokes the common law doctrine of disregarding the corporate cntity in addition to Section 45. Although in a given case the two approaches may come out at the same place, they appear to be theoretically distinct, since Section 45 proceeds upon the theory of reallocating income and deductions between existing entities, while disregard of the corporate entity is premised upon the postulate that the corporation has no realty but is a sham.

In an effort to prevent "spin-offs, split-ups, and split-offs" (see Holzman, Spin-Offs, Split-Ups, and Split-Offs, 5 NAT. TAX Jour. 277 (I952)) solely for tax purposes, the r95 I Act provided that where a corporation transfers all or a part of its property to a newly created or previously inactive corporation, which after the transfer is controlled by the transferor corporation or its stockholders, the transferee corporation loses the $\$ 25,000$ surtax exemption and minimum excess profits tax credit, unless it proves that obtaining the exception and credit was not a major purpose of the transfer. INr. Rev. Code $\$ 1_{5}(\mathrm{c})$, added by $\S \mathrm{I}_{2}(\mathrm{f})$, I95 I Act. The new provision is limited to transfers after January I, 195I, and is to remain in force only as long as the excess profits tax is in effect. Its probable efficacy seems questionable in view of the fact that it does not apply if it can be shown that tax avoidance was not a "major purpose" of the transfer.

"See Landman, Multiplying Business Corporations and Acquiring Tax Losses, 8 TAX L. REv. 8I (1952).

${ }^{45}$ INT. REv. CODE $\$ 19 \mathrm{r}$, added by $\$ 340(\mathrm{~b})$, r95 I Act.

${ }^{\circ} \mathrm{Id}$. $\$ \mathrm{I}_{2}(\mathrm{~d})$, added by $\S_{30 \mathrm{r}}$, 948 Act. (1947).

${ }^{47}$ But see Alexandre, The Corporate Counterpart of the Family Partnership, 2 TAX L. R'Ev. 493

\footnotetext{
${ }^{6}$ Overton v. Commissioner, 6 T. C. 304 (1946).
} 
of the deficit corporation. In an effort to plug this loophole Congress in 1943 added Section 129 to the Code, which provides that where a deficit corporation is purchased for the principal purpose of avoiding federal income or excess profits taxes by "securing the benefit of a deduction, credit, or other allowance" which the purchaser would not otherwise enjoy "then such deduction, credit or other allowance shall not be allowed." Unfortunately, the provision designed to plug the loophole soon developed its own loopholes and a lively market still exists for deficit corporations. Section 129 does not apply unless the principal purpose of the acquisition of the shell corporation was to take advantage of its credits or exemptions. If the loss corporation was acquired for some independent business reason, other than tax avoidance, Section 129 has no application. It seems fairly inferable from the fact that the Commissioner has so far failed to invoke Section I29 successfully in any case, that it is not very difficult to prove that the motive for acquiring a shell corporation was not tax avoidance. ${ }^{49}$ Section 129 may have a more serious defect. In several cases the Tax Court has intimated that Section 129 has no application where a deficit corporation is acquired and a profitable business is conveyed to the loss corporation. ${ }^{50}$ The basis of the argument is that in this case the shell corporation is entitled to apply its own credits and deductions against the income from the profitable business, because this is not a credit or deduction which it would not "otherwise enjoy." In other words apparently a profitable business cannot use the deductions and credits of a loss corporation. However, if a deficit corporation is acquired by a profitable business and the profitable business is transferred to the loss corporation, which continues to operate the business, there is no objection to using its credits and deductions. Obviously, if this line of reasoning is sound it robs Section r29 of any real significance. The "shell" corporation continues to operate as a "shell game" without any serious legal impediments.

D. Minimizing Taxes in Connection with the Withdrawal of Corporate Profits

Most schemes for avoiding taxes by diverting income to a corporation are dependent for their ultimate success upon the ability of the shareholders to withdraw the earnings which have accumulated in the corporation without incurring the individual tax at the time of withdrawal. The crudest way to do this, and the way which has the least chance of success if it is detected, is to disguise the withdrawal as a loan or some other form of tax-free advancement from the corporation to the stockholder. The tax law is not choosy about the form of a dividend. Any distribution of taxable corporate profits will be taxed as a dividend. If the disguise of a loan can be penetrated, and beneath judicial scrutiny it usually can, ${ }^{51}$ the so-called loan will be taxed as a dividend, with the further unpleasant possibility of a fraud penalty.

\footnotetext{
"Holzman, Who Wants a Tax Loss?, 20 The Controller 463 (1952); Landman, Multiplying Business Corporations and Acquiring Tax Losses, supra note 44.

${ }^{50}$ A. B. \& Container Corp. v. Commissioner, I4 T. C. 842 (1950); Commodores Point Terminal Corp. v. Commissioner, II T. C. 4II (I948); Alprosa Watch Corp. v. Commissioner, II T. C. 240 (I948).

${ }^{21}$ See, for example, Regensburg v. Commissioner, I44 F.2d 4 I (2d Cir. I944).
} 
The most satisfactory way to withdraw profits from a close corporation is to wait until the principal stockholder dies and liquidate the corporation. Upon the liquidation of a corporation, the redemption of the stockholders' stock is treated as a purchase of the stock by the corporation and taxable gain or loss is limited to the difference between the amount paid by the corporation to redeem the stock and the basis of the stock to the stockholders. ${ }^{52}$ When a stockholder dies his stock takes as its basis the fair market value of the stock at the date of his death, or one year after his death, if the optional valuation date is used for estate tax purposes. ${ }^{53}$ Since this will presumably be equal to, or greater than, the liquidating value of the stock, his share of the corporate profits can be withdrawn tax-free at his death by having the corporation liquidate and redeem his stock.

If the stockholders in a close corporation are not considerate enough to die in order to facilitate the withdrawal of the corporate profits without incurring the individual tax, the most economical way to get the profits out of the corporation is to liquidate so that the stockholders' gains will be taxed as long-term capital gains. Upon the complete liquidation of the corporation, since the redemption of the corporate stock is treated as a sale of the stock to the corporation, the stockholder will only be taxed upon the difference between what he receives and his basis for the stock. Ordinarily, moreover, the stock will represent a capital asset held by the stockholder for more than six months, so any gain will be a long-term capital gain subject to the favorable tax treatment accorded such profits.

Where a corporation is completely liquidated there is usually no difficulty about treating the stockholders' gains as long-term capital gains. In the case of a partial liquidation, however, where only part of the stock is redeemed, the income tax draws a difficult distinction between a genuine liquidation, which is treated as a sale or exchange of the stockholder's stock to the corporation, and a distribution of corporate profits disguised as a partial liquidation, which is taxed as an ordinary dividend. ${ }^{54}$ In the case of a close corporation particularly, a partial liquidation is almost always exposed to the hazard of being taxed as an ordinary dividend under Section $\operatorname{II} 5(\mathrm{~g}) .55$

One of the alleged advantages of "thin incorporation" is that corporate earnings

${ }^{62}$ INT. REv. CODE $\$ 115(c)$.

${ }^{63} I d . \$ 113(\mathrm{a})(5)$.

"“ Id. $\$ 115(\mathrm{~g})(\mathrm{I})$.

${ }^{65}$ See Bittker and Redlich, Corporate Liquidations and the Income Tax, 5 TAX L. Rev. 437, at 455480 (1950); Murphy, Partial Liquidations and the New Look, 5 TAx L. Rev. 73 (1949). In Commissioner v. Trustees Common Stock John Wanamaker Philadelphia, x78 F. 2d ro (3d Cir. 1949), it was held that the purchase of a parent corporation's stock by a subsidiary could not be taxed as an ordinary dividend under Section $115(\mathrm{~g})(\mathrm{r})$, because that Section applies only if a corporation cancels or redeems its own stock. The I950 Act provided that for taxable years beginning after August 3I, r950, the purchase of the stock by the subsidiary will be treated as though the subsidiary distributed the money used to purchase the stock to the parent, and the parent used the money to redeem its stock, and will be taxed as an ordinary dividend if the redemption of the stock by the parent would be an ordinary dividend. INT. REv. CODE $\$ 115(\mathrm{~g})(2)$, added by $\$ 208(\mathrm{e})$, I950 Act. Apparently, however, there is nothing to prevent one corporation from buying stock of another corporation which is controlled by the same interests. 
can be distributed to redeem bonds or pay off debts without subjecting the creditorstockholder to any tax if the distribution does not exceed the amount he has loaned to the corporation. It is assumed that Section $\operatorname{III}_{5}(\mathrm{~g})$ presents no problem in this connection because that Section refers to a redemption of stock, not bonds. If, however, the incorporation is so thin that a court will regard the borrowed capital as in substance equity capital, it would seem that the redemption of the corporation's bonded indebtedness might result in a taxable dividend under Section $115(\mathrm{~g}) .^{50}$

\section{E. Collapsible Corporations}

Where the rate differential between the corporate and individual taxes permits, one way of saving taxes by means of a corporation is to incorporate an enterprise and allow the income from the undertaking to be taxed in the first instance to the corporation, and then to liquidate the corporation and withdraw the profits in the form of long-term capital gains. The collapsible corporation, another Hollywood super-colossal production, refined on this plan by a stroke of sheer genius which eliminated the corporate tax by liquidating the corporation before any income was realized. Like most great ideas the scheme behind the collapsible corporation is basically simple. It is best illustrated by a typical example. Suppose that $A, B$, and $C$ decide to produce a motion picture from which they reasonably anticipate a profit of $\$ 3,000,000$. If they form a partnership and net $\$ 3,000,000$ from the picture in a single year, they will each be taxed upon ordinary income of $\$ \mathrm{r}, 000,000$, upon which, if they are married men whose wives have no independent income, the tax will be in the neighborhood of $\$ 873,000$, so the total tax will be $\$ 2,6 \mathrm{rg}, 000$. Consequently, the associates organize a corporation to produce the picture. After the picture is completed and the contracts have been made for its release, but before the corporation has realized any income from them, the associates liquidate the corporation and distribute the contracts to themselves in exchange for their stock. The corporation realizes no income. The stockholders incur a long-term capital gain to the extent of the difference between the fair market value of the contracts for the exhibition of the picture and the basis of their stock, upon which the maximum tax will be 26 per cent. Assuming that they invested $\$ x, 000,000$ in the corporation and that the contracts have a fair market value of $\$ 4,000,000$, they will realize a long-term capital gain of $\$ 3,000,000$ upon which the maximum tax will be 26 per cent, or $\$ 780,000$. If they subsequently realize no more from the exhibition of the picture than the fair market value assigned to the contracts, they will have no further income, because the amortization of the contracts will offset the receipts from the contracts.

This is the collapsible corporation which originated in the motion picture industry and had spread to other fields of endeavor, such as the building industry, before the r950 Act caught up with it by providing that any gain upon the liquidation of the corporation shall be taxed to the stockholders as ordinary income. ${ }^{67}$ Under the

${ }^{50}$ See Stein v. Commissioner, 46 B.T.A. 135 (1942), stupra note 13.

${ }^{57}$ INT. REv. CODE $\$ \operatorname{Ir}_{7}(\mathrm{~m})$, added by $\$ 212$, 1950 Act. The tax on collapsible corporations only 
present law, therefore, the associates in the hypothetical case would incur the same tax regardless of whether they operated as a collapsible corporation or partnership. It is perhaps too early to say whether the new provisions for taxing collapsible corporations will actually put an end to this interesting device.

The I950 Act, which was obviously drafted with a view to the use of the collapsible corporation in the motion picture and construction industries, only applied to corporations engaged in the manufacture, construction or production of property. It overlooked the situation where the same device was resorted to to convert profits from the sale of stock in trade into capital gain. For example, suppose that $A$ owns a large quantity of whiskey which he holds primarily for sale. $B$ wishes to purchase the whiskey, but if $A$ sells it to him directly the gain from the sale will be taxed as ordinary income. Consequently, $A$ organizes a corporation to which he makes a tax-free transfer of the whiskey under Section II2(b) (5) in return for all of the corporation's stock. $A$ sells the stock in the corporation to $B$, realizing a capital gain on the sale, and $B$ liquidates the corporation and gets the whiskey without incurring any further tax. ${ }^{58}$ Under the I $5^{1}$ Act, ${ }^{59}$ the tax on collapsible corporations was extended to this situation by taxing $A$ 's profit from the sale of the stock in the corporation as ordinary income. It is questionable, however, whether the tax on collapsible corporations is really effective to ban this device. For example, the tax only applies to a stockholder who owns directly or indirectly more than Io per cent of the stock of the collapsible corporation, ${ }^{60}$ which suggests that all that is needed to escape the tax is a bigger and better collapsible corporation with more diversified ownership. Moreover, the tax does not apply unless more than $7^{0}$ per cent of the gain realized from the sale of the stock is attributable to the property manufactured, constructed, produced or purchased by the corporation, and the gain is realized less than three years after the manufacture, construction, production or purchase, which obviously opens up some interesting avenues for speculation. Since the sale of an interest in a partnership is treated as the sale of a capital asset, ${ }^{61}$ it has been suggested that the result of a collapsible corporation might be obtained by a collapsible partnership. That is, the associates in the hypothetical case where the object of the venture was to produce a picture might, for example, form a partnership and make the picture and sell their interests in the partnership before any income was realized from the picture in order to convert their profits into long-term capital gains.

applies to years ending after 1949 and only to gains realized after December 31 , I949. It has been suggested that it would be possible to tax the gain from a collapsible corporation as ordinary income without any express legislative authorization to that effect. See Bittker and Redlich, supra note 55, at 439-448. But see Herbert v. Riddell, ro3 F. Supp. 369 (S. D. Calif. r952) (sustaining the validity of a pre-rgso collapsible corporation).

${ }^{58}$ Commissioner v. Gracey, 159 F. 2d 324 (5th Cir. 1947).

INT. REv. Code $\$ \operatorname{Ir}_{7}(\mathrm{~m})$, as amended by $\$ 326(\mathrm{a})$, I95I Act.

${ }^{10}$ In this connection stock ownership is deternined by the same rules which govern stock ownership in a personal holding company (INT. REv. Cope $\$ 503$ (a) (I), (2), (3), (5), and (6)), except that for the purpose of a collapsible corporation an individual's family also includes spouses of his brothers and sisters and spouses of his lineal descendants. INr. REv. CODE $\S \operatorname{Ir}(m)(3)$.

${ }^{01}$ G.C.M. 26379, 1950 I. C. B. 58 ; Swiren v. Commissioner, 183 F. 2d 656 (7th Cir. 1950). 
F. Fictitious Gains and Losses

A loss cannot be deducted under the income tax until it has been sustained or realized. In connection with the sale or exchange of property, this means that the taxpayer must part irrevocably with his interest in depreciated property before he can take a tax loss. Taxpayers have persistently attempted to circumvent this rule and deduct things like downward fluctuations in the market price of stocks or securities by more or less fictitious sales. One technique which has been tried, without any marked degree of success, has been to sell property to a corporation controlled by the seller. Apart from express legislative mandate the courts have refused to recognize such losses by disregarding the corporate entity and regarding the transaction as a sale by the taxpayer to himself. ${ }^{62}$ The statute now explicitly disallows losses upon sales or exchanges between a taxpayer and a controlled corporation, as well as losses connected with sales and exchanges between members of the same family and certain parties to trusts. ${ }^{63}$

The statutory disallowance of losses on sales between a stockholder and a controlled corporation does not extend to gains. Consequently, the practice grew up of selling depreciable property, which had a low tax basis, to a controlled corporation at a price substantially greater than the basis of the property. The tax advantage was that the taxpayer would incur a gain which would be taxed as a long-term capital gain under Section Ir7(j) of the Code, but the corporation would acquire a stepped-up basis for the property against which it could take a roo per cent deduction for depreciation. Recent legislation seeks to curb this practice by taxing the gains on such sales as ordinary income. ${ }^{64}$

\section{ConcLusion}

The object of this paper has been to present an unbiased critique of the current method of taxing the income from close corporations, rather than an exhaustive blueprint for tax avoidance. Consideration of the further possibilities of manipulating the corporate tax, which doubtless exist in particular situations, would merely serve to emphasize the inequities of the present system without adding materially to the aggregate discussion. There appears to be ample evidence of the inherent unsoundness of the current method of taxing the income of close corporations, and that this results primarily from the fact that tax is premised upon a legal fiction rather than economic realities.

The identification of the close corporation as an independent taxable entity interposes an unwarranted impediment to the free choice of a form of business organization. It is true that by careful tax management corporate taxes may be kept at a minimum, and, in a given situation, it may even be possible to operate more eco-

${ }^{02}$ Higgins v. Smith, 308 U. S. 473 (1940); but see Commissioner v. W. F. Trimble \& Sons Co., 98 F. 2d 853 (3d Cir. 1938); General Industries Corporation v. Commissioner, 35 B.T.A. 615 (1937) (A); Helvering v. Johnson, xo4 F. $2 \mathrm{~d}$ x40 (8th Cir. 1939), aff'd by an equally divided court, $308 \mathrm{U}$. S. 523 (1939).

${ }^{O 3}$ INT. REv. CODE $\$ 24(\mathrm{~b})$.

${ }^{64}$ Id. $\$$ II $7(0)$, added by $\$ 328$, I95I Act. See note ig supra. 
nomically as a corporation than as a partnership or sole proprietorship. The relative tax burdens of incorporated and unincorporated partnerships and proprietorships turn, however, upon the shrewdness of the taxpayer and his ability to outwit the tax collector, rather than the economic situation of the particular enterprise. The conduct of a business under the current system of taxing the income from close corporations becomes a matter where sound business practice must be subordinated to tax considerations.

The recognition of the corporation as a distinct taxable entity is a forceful inducement to tax avoidance. It is questionable just how effective the elaborate statutory paraphernalia for suppressing the tax maneuvers stimulated by the identification of the corporation as an independent taxable entity actually are. Upon the assumption, which is clearly unwarranted, that the statute provides perfect theoretical safeguards to prevent tax avoidance by the manipulation of the corporate tax, it is still uncertain how effectively these safeguards operate upon the practical level. There are a good many practices, like the deduction of losses on sales to controlled corporations or splitting up the income of a business by multiplying corporate entities, without any independent business reason for the division, which are constantly indulged in, because of ignorance or intent, and completely escape the eye of the tax gatherer. It requires incredible naivete to believe that taxpayers are actually aware of the abstruse safeguards against the misuse of the corporate device to avoid taxes, or that they observe them, if they are.

Since the objections to the present form of taxing the income from close corporations stem from the recognition of the corporation as an independent taxable entity, the obvious solution appears to be to disregard the corporate entity for tax purposes, and to tax the stockholders of a close corporation directly upon their distributive shares of the corporate income in the same way in which the income of a partnership is taxed to the partners. If a close corporation is simply a partnership or a sole proprietorship with a thin and taxwise immaterial corporate veneer, there is no reason for ignoring its true character for tax purposes.

The most sensible argument against ignoring the corporate entity and taxing the income of a close corporation directly to the stockholders is that this would involve certain administrative problems. It is difficult to believe, however, that the administrative difficulties would approximate the problems which are encountered in the administration of the present system of taxing corporate income and the constant controversies over where tax avoidance leaves off and tax evasion sets in. It is easy to exaggerate the administrative difficulties connected with taxing the shareholders of a close corporation upon their distributive shares of the corporate income by confusing the problem with the taxation of the income of widely held, publicly owned corporations. The attempt to determine the stockholders' shares of the income of a widely held public corporation, whose stock is constantly traded in, might well present an administrative nightmare. This problem does not exist, however, in the case of a close corporation, where stock ownership is as static as the ownership of a part- 
nership. For all practical purposes, save the accident of incorporation, a close corporation is a partnership. It would not be difficult to tax it as such.

The most difficult problem in connection with taxing the income of a close corporation like the income of a partnership, is to draw the line between close corporations, which are to be taxed in this way, and other corporations subject to the ordinary corporate tax. This should not, however, prove an insuperable obstacle. It would probably be unwise to draw the line at any arbitrary capitalization or number of stockholders. However, it would seem possible to make a distinction between those corporations whose stock is available to the public through a recognized exchange, or in over the counter markets, and those whose stock does not appear in any recognized market, or cannot be purchased without the consent of the corporate associates. ${ }^{65}$ In other words, following the partnership analogy, those corporations whose membership is as stable and selective as that of a partnership would be taxed as partnerships.

One danger in taxing a close corporation like a partnership is that this might be unfair to a minority stockholder, where those in control of the corporation refuse to distribute any dividends, since he would be obliged to pay a tax upon income which he could not reach, or even use to pay the tax. This again, however, does not seem to be an insuperable obstacle. It would be simple enough to empower the Commissioner to collect the tax due from the minority stockholder from the corporation, when he filed an appropriate declaration of his predicament.

Among the arguments which would undoubtedly be made against taxing the income of close corporations like the income of a parntership are that this would not allow a corporation to retain earnings needed for expansion, and that it would be unconstitutional. There appears to be no substance in the argument that a close corporation should be allowed to retain earnings without exposing them to a tax in the hands of the stockholders. Partners are taxed upon the part of the partnership income which is plowed back into the partnership business. If there is a practical parallel between a partnership and a close corporation, there is no reason why the stockholders of the close corporation should be treated differently.

The constitutional objection is scarcely more meritorious. Upon the assumption that there is no substantial difference between a close corporation and a partnership or a sole proprietorship, it would be fantastic to find that taxing the income of a close corporation in the same way in which the income of a partnership or proprietorship is taxed is so arbitrary or discriminatory that it violates due process. Apart from an attack upon the proposed plan for taxing the income from close corporations upon the score of the due process, the only other possible constitutional objection to

\footnotetext{
¿E I am indebted for this thought to my colleague Professor Elvin R. Latty, although I must take the responsibility for the vague and indefinite language in which $I$ have attempted to pass it on. The term "over-the-counter markets" is not to be interpreted, as it has sometimes been with respect to the application of the Securities Exchange Act, to include all transactions not on an organized stock cxchange, but as limited to transactions in the securities markets through professional channels. Sec Latty, The Aggrieved Buyer or Seller or Holder of Shares in a Close Corporation Under the S.E.C. Stattites (supra, pp. 505-534).
} 
the tax appears to be the shopworn argument that stockholders cannot be taxed upon their undistributed shares of corporate income, because they "realize" no income until the corporate profits are distributed to them. It is true that in Eisner $v$. $M_{a c o m b e r}{ }^{68}$ the Supreme Court refused to sustain the constitutionality of a tax upon stock dividends upon the theory that the tax was really a tax upon the stockholders' shares in the undivided profits of the corporation. The Court said that a tax upon the stockholders' shares of the undistributed income of the corporation would be an invalid direct and unapportioned tax upon capital, rather than a tolerated tax upon income under the Sixteenth Amendment, and that Collector $v$. Hubbard, ${ }^{67}$ which sustained such a tax in connection with the Civil War income tax acts, had been overruled by Pollock v. Farmers' Loan and Trust Co. ${ }^{68}$ It is barely possible that there may be some constitutional objection to taxing the income of a widely held, publicly owned corporation to the stockholders of the corporation before it is distributed to them. It is extremely unlikely, however, that the present Court, which has hinted broadly of its conviction that Eisner v. Macomber was decided incorrectly, ${ }^{60}$ would allow that case to stand in the way of a sane and rational system of taxing the income from close corporations.

If there is a constitutional objection to taxing the shareholders of a close corporation upon their distributive shares of the corporate income, the same result could easily be achieved by an undistributed profits tax, which the Supreme Court has held to be constitutional. ${ }^{70}$ A genuine undistributed profits tax, as distinguished from the abortive effort which appeared in the 1936 Act, ${ }^{71}$ except for accidental mechanical differences, does not differ in substance from taxing stockholders directly upon their distributive shares of corporate income. If the rate of tax is sufficiently stringent to compel corporations to distribute their earnings, the effect of the tax is not to tax the corporate income to the corporation, but to the shareholders to whom it must be distributed to avoid the tax.

${ }^{\circ 0} 252$ U. S. 189 (1920).

${ }^{\circ}{ }_{12}$ Wall. $x$ (U. S. I870).

${ }^{\circ 8} 158$ U. S. 6or (I895).

${ }^{\circ 0}$ Helvering v. Griffiths, 318 U. S. 37I (I943); see Lowndes, The Taxation of Stock Dividends and Stock Rights, 96 U. of PA. L. REv. 147 (1947).

${ }^{70}$ Helvering v. Northwest Steel Rolling Mills, 3 II U. S. 46 (1940).

${ }^{72}$ The president proposed a tax on undistributed profits which would compel corporations to distribute their earnings to their shareholders in whose hands the corporate carnings would be taxed, eliminating any corporate tax. Congress, however, watered down his proposal and enacted a measure whose rates were not sufficiently stringent to compel the distribution of corporate earnings, and which actually amounted to little more than an additional corporate income tax. 